\title{
Factors Associated with a Low Veterinary Regulatory Compliance in Uganda, Their Impact and Quality Management Approaches to Improve Performance
}

\author{
Wanderema S. N. Wesonga ${ }^{1}$, Bosco Madasi $^{2}$, Esther Nambo ${ }^{1}$ \\ ${ }^{1}$ Department of Animal Health, Ministry of Agriculture Animal Industry and Fisheries, Entebbe, Uganda \\ ${ }^{2}$ Government Technical Team (GTT) on Resettlement of Pastoralists in Mid-Western Region, Kasese, Uganda \\ Email:drwesonga2@yahoo.com,madasibosco@gmail.com, esthernambo@yahoo.com
}

How to cite this paper: Wesonga, W.S.N., Madasi, B. and Nambo, E. (2018) Factors Associated with a Low Veterinary Regulatory Compliance in Uganda, Their Impact and Quality Management Approaches to Improve Performance. Open Journal of Veterinary Medicine, 8, 207-231.

https://doi.org/10.4236/ojvm.2018.812019

Received: April 14, 2018

Accepted: December 3, 2018

Published: December 10, 2018

Copyright $\odot 2018$ by authors and Scientific Research Publishing Inc. This work is licensed under the Creative Commons Attribution International License (CC BY 4.0). http://creativecommons.org/licenses/by/4.0/

\section{Open Access}

\begin{abstract}
Organized veterinary services in Uganda were established in year 1908 and successfully controlled animal diseases nationally through a centralized chain of veterinary command. Such services were of public good, mandatory by regulations and also referred to as the "veterinary regulatory services". However, from 1993; policy reforms were introduced coincidentally at the same time with a national animal health passive surveillance system. Despite reforms, continued losses in livestock were observed necessitating a longitudinal survey based on the above surveillance system. Study findings were to serve as an indicator of performance for the reforms as regards animal disease control. Overall aim of the study was to: Confirm the assumed increase of disease after reforms; identify predisposing factors; gauge their impact and make recommendations to improve service delivery. Results confirmed that: Local government veterinary personnel reduced by $90.61 \%$ after the first year of decentralization; national animal health report submissions reduced from average of $81 \%$ to only $47.06 \%$ with a correlation or association of negative (-) $27.3 \%$ albeit at $\mathrm{p}$-value $>0.05$. Further, correlation at $\mathrm{p}$-value $<0.05$ confirmed that: Contagious and other major animal disease cases increased by $46.1 \%$; roundworm infestation in pigs increased by $69.4 \%$; field animal vaccine availability decreased by (-) $64.3 \%$ with time and a positive correlation of $65.3 \%$ was confirmed between human deaths and the number of bites by suspected rabid animals. Regression confirmed that with other factors held constant; on average: $69.5 \%$ of all Foot and Mouth Disease outbreaks in other areas of the country originated or depended on the same disease found in the cattle corridor while $42.7 \%$ human deaths from rabies was attributed to bites
\end{abstract}


from suspected rabid animals. Conclusion was that: Increased animal disease prevalence was primarily attributed to the reform policies but confounded by other veterinary institution internal and external/shock factors. This requires further policy reforms and a review of the national animal health passive surveillance system by all stakeholders to be done through and implemented by an efficient quality management system which is: staff-management-client focused.

\section{Keywords}

Chain of Veterinary Command, Reforms, Surveillance, Regulations, Quality Management

\section{Introduction}

\subsection{Relationships between Policy and the Delivery of Veterinary Regulatory Services}

Veterinary regulatory services protect the public and animals against: Health disasters or emergencies emanating from animals; ensure animal welfare and food safety; provide law and order in the livestock sector; regulate the veterinary profession and provide a level and fair playing field for livestock related trade. Failure to comply with the regulatory requirements leads to: Administrative sanctions such as imposing of animal movement controls and withdraw of inspections by the Chief Veterinary Officer (CVO) or penalties such as fines, jail and forfeiture of animal goods to the state through Courts of Laws [1]-[11]. The public good and mandatory nature of these services is historical since formal veterinary services were setup in the country in year 1908. Since then; the CVO whose title later changed to that of the Director Veterinary Services of the Protectorate for almost a century routinely used a centrally controlled chain of veterinary command for efficient compliance by stakeholders as regards animal disease control. This pre-reform stance ensured: prompt reporting of animal disease outbreaks from the field; immediate follow-up investigations and final diagnosis; carefully organized quarantine enforcement measures and prompt inoculations/vaccinations to suppress outbreaks of major diseases such as Rinderpest plague and Contagious Bovine Pleuro-Pneumonia. Such consistent regulatory stance led to only slight losses in livestock by 1926 and even by 1941 during World War II period which was noted for its population displacement; the veterinary services facilitated livestock trade bringing economic benefits to all in the country. This strategy up to the national independence of 1962 saw stability in animal health and animal production leading to eventual processing/canning of meat in Eastern Uganda at Soroti and accessing the international meat markets by late 1960s. Later with the need to change the delivery of veterinary services as was a national requirement for the various sectors due to economic hardships; main civil service reforms were introduced in the 
country from 1993-1997. Despite the reforms; it was however, later observed that the country faced about $70 \%$ in non-compliance with the veterinary regulations and that it had an estimated loss of 86.3 Million US\$ in the livestock sector annually attributed to disease [12].

For purposes of fulfilling their mandates, each organization or institution such as the national veterinary services requires: Short; medium and or long term policy frameworks. Policy frameworks include: Policies themselves; strategies to achieve the policies; laws and their: orders; rules; regulations; standards and procedures to enable mandatory compliance by the various livestock value chain stakeholders. When civil sector reforms and restructuring were introduced in Uganda: they were expected to use the scarce human; financial and time resources to enable efficient and quality oriented delivery of mandatory veterinary regulatory services. Just around the beginning of these reforms from 1993, a national animal health passive surveillance system was coincidentally also put in place. This was to: enable the systematic collection - reporting - collation - storage - retrieval - analysis - recommendation making - feedbacks to stakeholders and taking actions on animal disease threats in the whole country. Such a system would also be used passively in monitoring performance of animal health and production related projects or programs in the country by virtue of its functions and capacities. The coincidence of this system and its multi-functional capacity provided a scientific basis for its use in evaluation of performance of the reforms in animal health thus enabling this study.

\subsection{The Problem}

Despite civil sector policy and structural reforms especially from 1993-1997 as related to the delivery of veterinary regulatory services; there was continued observance of losses in the livestock sector per year attributed to disease. This required a study to verify such observances and recommend efficient strategies to address the problem.

\section{Literature Review}

\subsection{Policy and Structural Reforms in the Delivery of Veterinary Regulatory Services}

In recent past, many African countries underwent structural adjustment that often effectively dismantled services through decentralization thus sacrificing the chain of veterinary command required for quick response to disease emergencies and efficient reporting of outbreaks [13]. Such economic structural adjustment programs (reforms) have tended in several country cases to weaken the administrative, legal and financial capacity that are needed for dealing with (control of) major animal diseases [14]. Furthermore: while developed countries have advanced in veterinary science; use of sophisticated veterinary service infrastructure and use of area wide disease eradication and prevention measures-the situation in developing countries is different [15]. Such a weakened status requires 
the strengthening of state veterinary units to respond to regulatory responsibilities made mandatory by national laws and international standards on animal health [16]. Related; Uganda in 1987 started an economic recovery program which from 1990 resulted in structural reforms that liberalized agricultural input and output markets; trade and investment with year 1997 seeing enactment of the Local Government Act [17]. These actions and enactment of the Local Government Act legally decentralized the delivery of veterinary extension services away from the direct central chain of veterinary command of the CVO.

Reforms such as decentralization led to: political and legislative empowerment of the people; fiscal devolution and control of administrative machinery by the local councils with potential advantages and serious challenges [18]. Related, while it further reduced the central overload and duplication of work; decentralization for veterinary services however, also reduced central government's regulatory and supervisory roles that is essential in animal disease control [19]. While Uganda achieved impressive economic growth and poverty reduction (related to reforms) over the past two decades; it declined in relative importance of agriculture (including livestock) with limited structural transformation of the economy [20]. Related to this decline as one looks at the challenges from the reforms since 1993; more specific policies to promote agricultural production including livestock largely failed while the National Agricultural Advisory Services success also remained contested since they were seen as being weak and expensive [21]. The National Agricultural Advisory Services Program from 2001 initially considered as a role model for demand-driven, decentralized and market-oriented agricultural extension reform in Africa despite adequate resources available had limited success [22]. It has thus been noted that; decentralization has not and will not necessarily lead to better outcomes due to the highly variable environment exampled by several decentralization and recentralization efforts made of the Forestry Department Uganda [23].

\subsection{Animal Health Surveillance in the Delivery of Veterinary Regulatory Services}

It has been noted that animal health surveillance is an essential tool for: the detection of animal disease or infections; monitoring disease trends and for facilitating the control of disease or infection [24]. Thus even in historical times as part of animal disease surveillance; organized veterinary services since 1908 in Uganda were devoted to the control of Rinderpest and Contagious Bovine Pleuro Pneumonia epidemics among others earlier supervised by the CVO Kenya [25]. In further support to the importance of animal health surveillance and efficiency of related programs: it was noted in Africa during Rinderpest plague control by Joint Program (JP) 15 from 1962 that while the disease significantly decreased however, resurgence later recurred due to inadequate national follow-up [26]. Related to the importance of surveillance; it has been observed in Uganda that FMD occurs more frequently: in dry season; near wild life reserves; near in- 
ternational borders; is related to animal movements and is introduced by infected animals [27]. Using a related passive surveillance system in the sister health sector; it was possible to estimate mortality of human patients from rabies due to animal bites at national level but requiring active surveillance to improve the mortality rates [28]. This highlights the importance and challenges of passive surveillance. With the continued high threats of animal diseases to economic progress in Africa; surveillance has become an essential tool for early disease detection and rapid response [29]. However; components (used) in a surveillance system must be justified since-a costly and extensive surveillance system may cause more harm than good [30]. Because of such a scenario-in Africa, alternative cheap animal health (surveillance) information may be got from various stakeholders along the livestock value chain [31].

Uganda's national animal health passive surveillance system used in this study also reported and monitored veterinary drug availability and their use in the field at extension level. Reforms in the country led to veterinary drug supply chain: liberalization - divestiture and privatization leaving veterinary services to be directly responsible for only four (now five) animal epidemic disease related vaccines [32]. Despite the reformed national veterinary drug policy whose technical responsibility was given to the veterinary services; the actual physical control and regulatory enforcement of compliance remained by law/regulation under a different sector-the Ministry of Health [9]. On a positive note-reforms in Uganda have increased and improved farmers' access to veterinary drugs but that quality control should be addressed and government should have a role in stabilizing the escalating prices and the supply gaps [19].

\subsection{Governance, Insecurity and Quality Management in the Delivery of Veterinary Regulatory Services}

It has been noted that; good governance is a global public good which is of critical importance to the World Organization for Animal Health (OIE) Member Countries - Uganda inclusive with legislation (regulations) being a key element for its achievement [33]. Policy frameworks including regulations when enforced or complied with lead to good governance. Further; good governance enablesservices that are sustainably: financed; universally available; efficient without waste or duplication; transparent and free of corruption for sustainable economic development [34]. Unfortunately; it has been observed that poor governance has been existing and a major issue in many African countries that can significantly occlude capacity of governments to promote development [35].

As a factor affecting governance/transparence and thus service delivery - conflict among others has been viewed as leading to lawlessness, insecurity and disorder in a society. Related; it has been observed that Uganda for more than the last three decades experienced protracted civil conflict in form of: civil war; catthe raiding and armed banditry in the north [36]. Further; it has been noted that the incidence and distribution of rabies disease in Uganda has been influenced 
directly or indirectly by the different political regimes and thus their styles of governance overtime [37]. Rabies was further linked to insecurity when a high population of stray dogs left behind by displaced people in rural areas of North and Western parts of Uganda which experienced civil strife moved to urban areas requiring dog population control strategies to minimize the disease [38]. Related; an increase in rabies had been noted in man in Sierra Leon in urban areas during civil war due to breakdown in vaccinations and inability to control freely roaming and wondering but owned dog pets [39]. Furthermore, it was observed that the 1994 civil disturbances/conflict in Rwanda saw sudden and heavy migrations of people and livestock followed by widespread outbreaks of major animal diseases such as FMD and Contagious Bovine Pleuro Pneumonia in the Region - Uganda inclusive [14].

In regard to good governance; the veterinary authorities have been noted to have a mandate to provide quality services to meet fundamental principles of ethical, organizational, legislative, regulatory and technical nature regardless of the: political; economic or social situation in their country [33]. To offer quality services; the veterinary services are advised to document a quality policy and ensure that it is: understood; maintained and implemented at all levels of organization and where possible to use an appropriate quality management system [40]. However, the term quality as related to the delivery of services may not be well understood by all stakeholders. Related to this gap in understanding of this term-it has been noted that even the quality management issue itself attracts less attention. A related situation of this gap has further been noted in lack of quality management research and with little link to performance [41]. Other than mainly in the food quality and its safety-other areas in livestock have seen little research on quality for even the mandatory/regulatory services offered to stakeholders.

Quality desires of services for institutions such as the national veterinary services are better managed through specific Quality Management Systems to enable achievement of the goals. On research between relationships/correlation of Quality Management Practices and organizational performance-it has been observed that Quality Management (QM) philosophy known as Employees - Customers - Owners can be used in which when employees are happy; they go a long way to provide world class (good) customer services [42]. This position has also been supported highlighting QM importance in productivity and performance of an organization [43]. Further, a study also indicated that QM may be a source of competitive advantage with top management leadership and supplier management playing a critical part in improving organizational performance [44]. QM practices are related to improvement in organizational services/output/productivity and profitability. Without exception: the delivery of effective; efficient and well governed veterinary regulatory services requires a Quality Management System as advocated by the OIE to enable QM practices [40]. 


\subsection{Different Livestock Production Systems in the Delivery of Veterinary Regulatory Services}

Livestock Production Systems consist of an assembly of related components that combine for some common reason or purpose in which any introduction of change or interference becomes a complex [31]. Related; with the many diverse livestock production systems in the world, Africa inclusive of which some are vulnerable; it would require careful planning for any changes or reforms to be introduced including in animal health. This is so given that the world has an inability to detect; report and control animal disease especially for small livestock holders and pastoralists [45] thus facilitating disease spread and effects. As regards the vulnerable types of livestock production systems in Uganda, it has been noted that Soroti and Kayunga districts which practice small holder mixed farming face challenges in: animal health; water; animal feeds and experience high economic losses in animals [46]. Further to this; it has been observed that pigs which scavenge and are free range fed (not confined) are prone to animal health and food safety compromising infections [47].

Economically; it has been observed that livestock offer to the poor farmers an important path-way out of poverty trap using healthy livestock (not sick animals) that provide a rich variety of assets and commodities [48]. Further, the poor livestock farmers can benefit from livestock if the three value chain roadblocks of: vulnerability reduction on animal disease shocks; intensification of farming; increased production and market access are followed [49]. While intensification of livestock production will lead to larger units and increased global trade; it will however, also increase the resurgence of serious animal diseases and public health-related problems [16].

\subsection{Globalization of the: Economy; Adverse Climate Changes and Epidemics in the Delivery of Veterinary Regulatory Services}

Globalization manifests itself in: many sectors of the economy leading to increases in worldwide trade and exchanges that includes the livestock sector [50]. Related to globalization; in Uganda - global adverse climatic change has predisposed to more rainfall from December-February than previously, with increasing warming trend that will affect agriculture and livestock thus increasing risks of disease and pest infestations [51]. It has further been noted that: Africa will bear heavier burden in coping with climate change and its far-reaching impacts on food security, health, energy, migration and conflict [52]. This by extrapolation would among others pose: ecological/environmental; animal health; public health; animal welfare; livestock productivity and household farm family poverty risks. In relationship to global eco-system changes and susceptibilities-recent comprehensive literature review identified that $61 \%$ of pathogens in man can be transmitted between humans and animals with $75 \%$ of the emerging diseases in man being zoonotic/of public health importance [53]. Global: economics, climatic changes and epidemic prevalence do impact the delivery of veterinary reg- 
ulatory services.

\subsection{Overall Aim of the Study Work}

It was to: verify the assumed animal disease prevalence increases during the policy reform period; factors responsible; their impact and quality management strategies to improve delivery of the veterinary regulatory services. The overall aim was achieved.

\section{Materials and Methods}

\subsection{Research Design}

A longitudinal survey method bringing on board the quantitative and descriptive aspects was used to statistically analyze data from the national animal health passive surveillance system collected continuously for 16 years from all the district of Uganda-with each district identified by name [54] \& [55]. This study method and approach was further supported [56] since animal health surveillance information gathered from the same country, zone or compartment at different times may provide cumulative evidence of animal health status that over time may be combined to provide an overall level of confidence when analyzed.

\subsection{Sample Frame and Size}

A district was used as a sampling frame/strata with an expected representative sample of one animal health report submitted per month using a structured survey tool per district by the District Veterinary Officers (DVOs). This was expected to give $100 \%$ sampling per month for the study period under consideration.

\subsection{Data Accrued}

The primary data used was from the national animal health passive surveillance system obtained through a designed survey tool used in the submission of animal health reports per month by each district in the whole country, while secondary data was from the national animal health active surveillance system and other related animal health information systems.

\subsection{Data Collection}

Pre-designed and pre-tested structured survey report formats (questionnaires or the survey tool) were used for the collection of data since 1993 but with years 1996 to 1999, 2001 to 2012 (16 years) available in an electronic viable form for retrieval and analysis. Year 2000 was not viable.

\subsection{Data Analysis}

Two computer based applications we used for analysis. The Micro Soft Excel 2007 to: support the retrieved data; verification; sorting; coding and for specific graphical presentations and the Statistical Package for Social Sciences Version 16 
(SPSS V.16) to determine the: descriptive statistics for "animal health" status and trends, relationships/associations (correlation) and impacts of associations (regression) at $95 \%$ confidence level or 5\% margin of error. Results were presented in form of analytical tables and figures.

\section{Results}

Table 1 shows varying yearly mean animal health report submissions from all Districts in the country from year 1996-1999, 2001-2012.

Figure 1 shows varying trends in the animal health report submissions with time

Figure 2 shows a scatter diagram indicative of diminishing or negative mean returns' trend with time for animal health report submissions.

Table 2 shows a maximum of $89.732 \%$, a minimum of $12.723 \%$ and a mean of only $47.06 \%$ for the submission of animal health reports in 16 years with a wide submission standard deviation of $24.41 \%$ from the mean obtained. The valid list of years for submissions considered was 16 with details of the years reflected in Table 1 listwise.

Table 3 in reference to details in Table 1 showed a negative (-) but weak Pearson Correlation Co-efficient (correlation or association) of $27.3 \%$ albeit at $p$-value $>0.05$ for submission of the animal health reports indicatively decreasing with time at a rate of $27.3 \%$ in 16 years. Statistical significance was at $p$-value $<$ 0.05 .

Table 1. Mean animal health report submissions with time.

\begin{tabular}{cccccc}
\hline $\begin{array}{c}\text { Year of } \\
\text { submission } \\
\text { list wise }\end{array}$ & $\begin{array}{c}\text { Number of } \\
\text { Districts }\end{array}$ & $\begin{array}{c}\text { Submitting } \\
\text { Districts }\end{array}$ & $\begin{array}{c}\text { Expected } \\
\text { submissions }\end{array}$ & $\begin{array}{c}\text { Actual } \\
\text { submissions }\end{array}$ & $\begin{array}{c}\text { Mean submissions } \\
\text { per year (\%) }\end{array}$ \\
\hline 1996 & 39 & 36 & 468 & 303 & 64.74358974 \\
1997 & 44 & 34 & 528 & 230 & 43.56060606 \\
1998 & 44 & 23 & 528 & 147 & 27.84090909 \\
1999 & 44 & 23 & 528 & 83 & 15.71969697 \\
2001 & 56 & 35 & 672 & 309 & 45.98214286 \\
2002 & 56 & 51 & 672 & 543 & 80.80357143 \\
2003 & 56 & 56 & 672 & 603 & 89.73214286 \\
2004 & 56 & 56 & 672 & 558 & 83.03571429 \\
2005 & 78 & 50 & 936 & 461 & 49.25213675 \\
2006 & 86 & 73 & 1032 & 538 & 52.13178295 \\
2007 & 86 & 74 & 1032 & 664 & 64.34108527 \\
2008 & 86 & 46 & 1032 & 287 & 27.81007752 \\
2009 & 100 & 23 & 1200 & 187 & 15.58333333 \\
2010 & 112 & 27 & 1344 & 171 & 12.72321429 \\
2011 & 112 & 87 & 1344 & 596 & 44.3452381 \\
2012 & 112 & 77 & 1344 & 476 & 35.41666667 \\
\hline & & & & & \\
\hline
\end{tabular}


Table 2. Descriptive statistics for submission of animal health reports with time.

\begin{tabular}{|c|c|c|c|c|c|c|c|c|}
\hline \multicolumn{9}{|c|}{ Descriptive Statistics } \\
\hline & $\mathrm{N}$ & Minimum & Maximum & Mean & $\begin{array}{l}\text { Standard } \\
\text { Deviation }\end{array}$ & Variance & Skewness & \\
\hline & Statistic & Statistic & Statistic & Statistic & Statistic & Statistic & Statistic & $\begin{array}{c}\text { Standard } \\
\text { Error }\end{array}$ \\
\hline $\begin{array}{c}\text { Level of } \\
\text { Submission }\end{array}$ & 16 & 12.723 & 89.732 & $4.7063 \mathrm{E} 1$ & 24.418509 & 596.264 & 0.288 & 0.564 \\
\hline $\begin{array}{l}\text { Valid N } \\
\text { (Listwise) }\end{array}$ & 16 & & & & & & & \\
\hline
\end{tabular}

Table 3. Correlation for submission of animal health reports with time.

\begin{tabular}{cccc}
\hline & \multicolumn{2}{c}{ Correlations } & \\
\hline & & Year of Submission & Level of Submission \\
\hline & Pearson Correlation & 1 & -0.273 \\
Year of Submission & Sig. (2-tailed) & 16 & 0.306 \\
& $\mathrm{~N}$ & -0.273 & 16 \\
Level of Submission & Pearson Correlation & 0.306 & 1 \\
& Sig. (2-tailed) & $\mathrm{N}$ & 16 \\
\hline
\end{tabular}

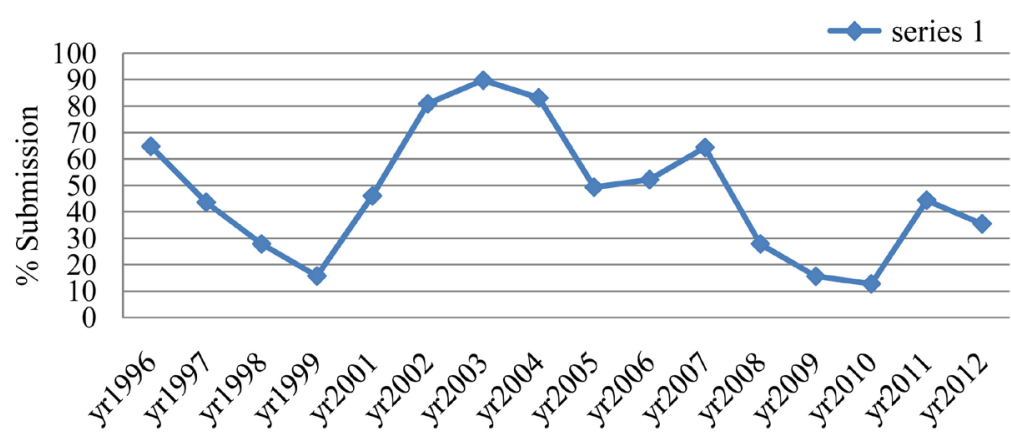

Figure 1. Trends in submission of animal health reports with time.

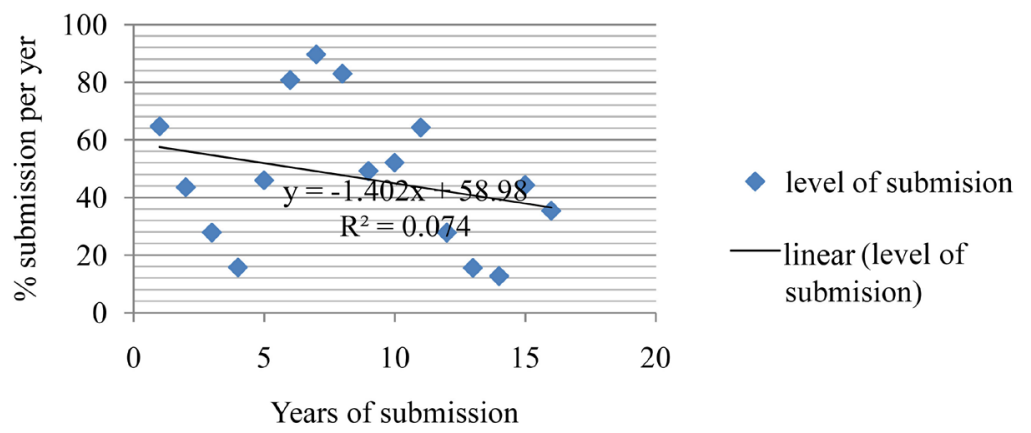

Figure 2. Scatter diagram for submission of animal health reports with time.

Table 4 shows a fairly positive correlation of $46.1 \%$ at $p$-value $<0.05$ between cases of sick animals due to contagious and other major diseases with time. It 
means that the number of sick animals increased at a rate of $46.1 \%$ in 16 years during the period of study.

Table 5 shows a very strong positive correlation of $83.3 \%$ at $p$-value $<0.05$ of FMD outbreak within or in the cattle corridor areas of Uganda in 10 years and its occurrence outside the cattle corridor areas. The cattle corridor in Uganda and beyond is largely semi-arid during the dry season and thus largely inhabited by pastoralists and communal livestock grazing as major livestock production systems.

Table 4. Correlation for cases of animals sick from contagious and other major diseases with time.

\begin{tabular}{|c|c|c|c|c|}
\hline \multicolumn{5}{|c|}{ Correlations } \\
\hline & & $\begin{array}{c}\text { Year of } \\
\text { Submission }\end{array}$ & $\begin{array}{c}\text { Number of } \\
\text { Animals at Risk }\end{array}$ & $\begin{array}{c}\text { Number of } \\
\text { Animals Sick }\end{array}$ \\
\hline \multirow{3}{*}{$\begin{array}{c}\text { Year of } \\
\text { Submission }\end{array}$} & Pearson Correlation & 1 & 0.630 & 0.461 \\
\hline & Sig. (1-tailed) & & 0.004 & 0.036 \\
\hline & $\mathrm{N}$ & 16 & 16 & 16 \\
\hline \multirow{3}{*}{$\begin{array}{c}\text { Number of } \\
\text { Animals at Risk }\end{array}$} & Pearson Correlation & 0.630 & 1 & 0.738 \\
\hline & Sig. (1-tailed) & 0.004 & & 0.001 \\
\hline & $\mathrm{N}$ & 16 & 16 & 16 \\
\hline \multirow{3}{*}{$\begin{array}{c}\text { Number of } \\
\text { Animals Sick }\end{array}$} & Pearson Correlation & 0.461 & 0.738 & 1 \\
\hline & Sig. (1-tailed) & 0.036 & 0.001 & \\
\hline & $\mathrm{N}$ & 16 & 16 & 16 \\
\hline
\end{tabular}

${ }^{*}$ Correlation is significant at the 0.05 level (1-tailed).

Table 5. Correlation of FMD outbreaks within the cattle corridor and outside the corridor.

\begin{tabular}{|c|c|c|c|c|}
\hline \multicolumn{5}{|c|}{ Correlations } \\
\hline & & $\begin{array}{l}\text { Year of FMD } \\
\text { Outbreak }\end{array}$ & $\begin{array}{l}\text { Number of FMD } \\
\text { Outbreaks in the } \\
\text { Cattle Corridor }\end{array}$ & $\begin{array}{l}\text { Number of FMD } \\
\text { Outbreaks Outside the } \\
\text { Cattle Corridor }\end{array}$ \\
\hline \multirow{3}{*}{$\begin{array}{c}\text { Year of FMD } \\
\text { Outbreak }\end{array}$} & Pearson Correlation & 1 & 0.204 & 0.291 \\
\hline & Sig. (2-tailed) & & 0.572 & 0.415 \\
\hline & $\mathrm{N}$ & 10 & 10 & 10 \\
\hline \multirow{3}{*}{$\begin{array}{l}\text { Number of FMD } \\
\text { Outbreaks in the } \\
\text { Cattle Corridor }\end{array}$} & Pearson Correlation & 0.204 & 1 & 0.833 \\
\hline & Sig. (2-tailed) & 0.572 & & 0.003 \\
\hline & $\mathrm{N}$ & 10 & 10 & 10 \\
\hline \multirow{3}{*}{$\begin{array}{l}\text { Number of FMD } \\
\text { Outbreaks Outside } \\
\text { the Cattle Corridor }\end{array}$} & Pearson Correlation & 0.291 & 0.833 & 1 \\
\hline & Sig. (2-tailed) & 0.415 & 0.003 & \\
\hline & $\mathrm{N}$ & 10 & 10 & 10 \\
\hline
\end{tabular}

${ }^{* *}$ Correlation is significant at the 0.05 level (2-tailed). 
Table 6(a) \& Table 6(b): show a Regression Co-efficient (regression) of a strong $69.5 \%$ at $p$-value $<0.05$ of FMD outbreaks between the cattle corridor and outside the cattle corridor areas. It meaning that with other factors held constant, on average a high $69.5 \%$ of all changes/variations or occurrences in FMD outbreaks in areas outside the cattle corridor (a dependent variable) in Uganda are attributed or dependent or originate from FMD outbreaks in the cattle corridor areas (an independent/predictor/constant variable).

Table 7 shows correlation between human deaths from rabies and the number of bites in man from suspected rabid animals at a fairly strong positive $65.3 \%$ at $p$-value $<0.05$. The higher the number of bites by suspected rabid animals, the more deaths from Rabies was reported in man in 15 years.

Table 8(a) \& Table 8(b): show a fair regression of $42.7 \%$ at $p$-value $<0.05$ between the number of bites in man from suspected rabid animals and humans deaths from rabies. This means that with other factors held constant, on average: $42.7 \%$ of all human deaths or changes in human deaths are dependent on bites from suspected rabid animals.

Table 9 shows a strong positive correlation of $69.4 \%$ at $p$-value $<0.05$ meaning that the roundworm condition increased with time.

Table 10(a) \& Table 10(b): show impact of the relationship between roundworm infestation in pigs and time in years with a regression on average of $48.2 \%$ at $p$-value $<0.05$. This means that with other factors held constant, on average: $48.2 \%$ of all observations seen in round worm prevalence at meat inspection in pigs are attributed on the time of submission (years of submission).

Table 11 shows relationship between the issuance of doses of vaccines by

Table 6. (a) \& (b) Regression of FMD occurrence in the cattle corridor and outside the corridor.

(a)

\begin{tabular}{ccccc}
\hline \multicolumn{4}{c}{ Regression } \\
\hline Model & $\mathrm{R}$ & R Square & $\begin{array}{c}\text { Adjusted R } \\
\text { Square }\end{array}$ & $\begin{array}{c}\text { Standard Error of the } \\
\text { Estimate } \\
1\end{array}$ \\
\cline { 3 - 4 } & $0.833^{\mathrm{a}}$ & 0.695 & 0.657 & 2.627 \\
\hline
\end{tabular}

aPredictors: (Constant), Number of FMD outbreaks in the cattle corridor.

(b)

\begin{tabular}{cccccc}
\hline \multicolumn{7}{c}{ Coefficients $^{\mathbf{a}}$} & & & \\
\hline Model & \multicolumn{1}{c}{ Unstandardized Coefficients } & $\begin{array}{c}\text { Standardized } \\
\text { Coefficients }\end{array}$ & $\mathrm{t}$ & Sig \\
\cline { 2 - 4 } & $\mathrm{B}$ & Standard Error & Beta & & \\
\hline (Constant) & 1.318 & 1.395 & & 0.945 & 0.373 \\
$\begin{array}{c}\text { Number of FMD Outbreaks } \\
\text { in the cattle Corridor }\end{array}$ & 0.352 & 0.082 & 0.833 & 4.267 & 0.003 \\
\hline
\end{tabular}

${ }^{a}$ Dependent Variable: Number of FMD outbreaks outside the cattle corridor. 
Table 7. Correlation of the number of bites in man by suspected rabid animals and human deaths from rabies.

\begin{tabular}{|c|c|c|c|c|}
\hline \multicolumn{5}{|c|}{ Correlations } \\
\hline & & $\begin{array}{c}\text { Number of } \\
\text { suspected cases in } \\
\text { animals per year }\end{array}$ & $\begin{array}{c}\text { Number of } \\
\text { bites by suspected } \\
\text { animals per year }\end{array}$ & $\begin{array}{c}\text { Number of cases in } \\
\text { human (those who } \\
\text { died) pear year }\end{array}$ \\
\hline \multirow{3}{*}{$\begin{array}{c}\text { Number of } \\
\text { suspected cases in } \\
\text { animals per year }\end{array}$} & Pearson Correlation & 1 & 0.812 & 0.371 \\
\hline & Sig. (2-tailed) & & 0.000 & 0.174 \\
\hline & $\mathrm{N}$ & 15 & 15 & 15 \\
\hline \multirow{3}{*}{$\begin{array}{l}\text { Number of bites } \\
\text { by suspected } \\
\text { animals per year }\end{array}$} & Pearson Correlation & 0.812 & 1 & 0.653 \\
\hline & Sig. (2-tailed) & 0.000 & & 0.008 \\
\hline & $\mathrm{N}$ & 15 & 15 & 15 \\
\hline \multirow{3}{*}{$\begin{array}{l}\text { Number of cases } \\
\text { in human } \\
\text { (those who died) } \\
\text { pear year }\end{array}$} & Pearson Correlation & 0.371 & 0.653 & 1 \\
\hline & Sig. (2-tailed) & 0.174 & 0.008 & \\
\hline & $\mathrm{N}$ & 15 & 15 & 15 \\
\hline
\end{tabular}

Table 8. (a) \& (b) Regression of the number of bites in man from suspected rabid animals and human deaths from rabies.

(a)

\begin{tabular}{ccccc}
\hline \multicolumn{5}{c}{ Regression } \\
\hline & & \multicolumn{3}{c}{ Model Summary } \\
\hline Model & $\mathrm{R}$ & R Square & Adjusted R Square & Standard Error of the Estimate \\
\hline 1 & $0.653 \mathrm{a}$ & 0.427 & 0.383 & 149.285 \\
\hline
\end{tabular}

${ }^{\text {a} P}$ Predictors: (Constant), Number of bites made by suspected animals per year.

(b)

\begin{tabular}{|c|c|c|c|c|c|}
\hline \multicolumn{6}{|c|}{ Coefficients $^{\mathrm{a}}$} \\
\hline \multirow{2}{*}{ Model } & \multicolumn{2}{|c|}{ Unstandardized Coefficients } & \multirow{2}{*}{$\begin{array}{c}\begin{array}{c}\text { Standardized } \\
\text { Coefficients }\end{array} \\
\text { Beta }\end{array}$} & \multirow{2}{*}{$\mathrm{t}$} & \multirow{2}{*}{ Sig } \\
\hline & B & Standard Error & & & \\
\hline (Constant) & -61.499 & 66.589 & & -0.924 & 0.373 \\
\hline $\begin{array}{l}\text { Number of bites } \\
\text { by suspected } \\
\text { animals per year }\end{array}$ & 0.066 & 0.021 & 0.653 & 3.112 & 0.008 \\
\hline
\end{tabular}

a Dependent Variable: Number of cases in human (those who died) per year.

Table 9. Correlation of roundworm infestation condition in pigs with time.

\begin{tabular}{cccc}
\hline \multicolumn{4}{c}{ Correlations } \\
\hline & Year of Submission & Round worms \\
\hline \multirow{3}{*}{ Year of submission } & Pearson Correlation & 1 & 0.694 \\
& Sig. (2-tailed) & & 0.038 \\
& N & 9 & 9 \\
Round worms & Pearson Correlation & 0.694 & 1 \\
& Sig. (2-tailed) & 0.038 & 9 \\
\hline
\end{tabular}


Table 10. (a) \& (b) Regression of roundworm infestation condition in pigs with time.

(a)

\begin{tabular}{ccccc}
\hline \multicolumn{4}{c}{ Regression } \\
\hline \multicolumn{4}{c}{ Model Summary } \\
\hline Model & $\mathrm{R}$ & R Square & Adjusted R Square & Standard Error of the Estimate \\
\hline 1 & $0.694^{\mathrm{a}}$ & 0.482 & 0.408 & 840.373 \\
\hline
\end{tabular}

aPredictors: (Constant), Year of submission.

(b)

\begin{tabular}{|c|c|c|c|c|c|}
\hline \multicolumn{6}{|c|}{ Coefficients $^{\mathrm{a}}$} \\
\hline \multirow[t]{2}{*}{ Model } & \multicolumn{2}{|c|}{$\begin{array}{l}\text { Unstandardized } \\
\text { Coefficients }\end{array}$} & \multirow{2}{*}{$\begin{array}{c}\text { Standardized } \\
\text { Coefficients } \\
\text { Beta }\end{array}$} & \multirow[t]{2}{*}{$\mathrm{t}$} & \multirow[t]{2}{*}{ Sig } \\
\hline & B & Standard Error & & & \\
\hline (Constant) & 397.306 & 610.517 & & 0.651 & 0.536 \\
\hline Year of Submission & 276.917 & 108.492 & 0.694 & 2.552 & 0.038 \\
\hline
\end{tabular}

${ }^{\mathrm{a} D e p e n d e n t ~ V a r i a b l e: ~ R o u n d ~ w o r m s . ~}$

Table 11. Correlation of vaccines doses issued by DVOs for field use with time.

\begin{tabular}{cccc}
\hline & \multicolumn{3}{c}{ Correlations } \\
\hline & Year of Submission & Quantity issued in doses \\
\hline \multirow{2}{*}{ Year of submission } & Pearson Correlation & 1 & -0.643 \\
& Sig. (2-tailed) & & 0.010 \\
& $\mathrm{~N}$ & 15 & 15 \\
Quantity issued & Pearson Correlation & -0.643 & 1 \\
in doses & Sig. (2-tailed) & 0.010 & 15 \\
\hline
\end{tabular}

DVOs for use in the field with time. It shows a fairly strong but negative relationship with a correlation of negative or minus $(-) 64.3 \%$ at $p$-value $<0.05$. Meaning vaccine issuance/usage or availability reduced with time at a rate of $64.3 \%$ in 15 years.

Table 12(a) \& Table 12(b): show a regression at a fair level of $41.3 \%$ at $p$-value $<0.05$. This means that with other factors held constant; on average $41.3 \%$ of the variations or quantities of vaccines issued for use in the field were attributed or dependent on the year or time when the animal health reports were submitted.

Figure 3 shows changes in numbers of different cadres of the local governments (the decentralized veterinary personnel) during the reform period in which there was a very sharp fall for years 1997-1998 from 970 to only 91 personnel (a decrease by 90.61\%) during the study period. Thereafter, there was a very slow trend of increments in staffing at the local governments. The increments included private veterinary practitioners as part of the reforms introduced. 
Table 12. (a) \& (b) Regression of vaccines doses issued by DVOs for field use with time.

(a)

\begin{tabular}{ccccc}
\hline \multicolumn{4}{c}{ Regression } \\
\hline Model & $\mathrm{R}$ & R Square & $\begin{array}{c}\text { Adjusted R } \\
\text { Square }\end{array}$ & Standard Error of the Estimate \\
\hline 1 & $0.643^{\mathrm{a}}$ & 0.413 & 0.368 & 790790.312 \\
\hline
\end{tabular}

${ }^{\mathrm{a} P r e d i c t o r s: ~(C o n s t a n t), ~ Y e a r ~ o f ~ s u b m i s s i o n . ~}$

(b)

\begin{tabular}{|c|c|c|c|c|c|}
\hline \multicolumn{6}{|c|}{ Coefficients $^{\mathrm{a}}$} \\
\hline \multirow[t]{2}{*}{ Model } & \multicolumn{2}{|c|}{ Unstandardized Coefficients } & \multirow{2}{*}{$\begin{array}{c}\text { Standardized } \\
\text { Coefficients }\end{array}$} & \multirow[t]{2}{*}{$\mathrm{t}$} & \multirow[t]{2}{*}{ Sig } \\
\hline & B & Standard Error & & & \\
\hline (Constant) & $2.636 \mathrm{E} 6$ & $423,864.024$ & & 6.218 & 0.000 \\
\hline Year of Submission & $-139,287.801$ & $46,046.795$ & -0.643 & -3.025 & 0.010 \\
\hline
\end{tabular}

${ }^{a}$ Dependent Variable: Quantity issued in doses.

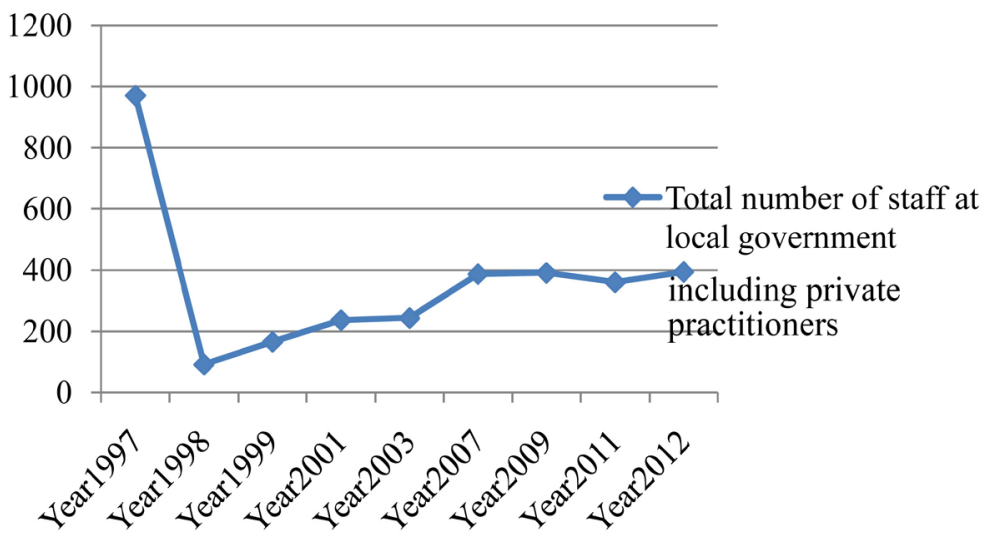

Figure 3. Post reform policy effects on the local government veterinary staffing.

\section{Discussion}

\subsection{Verification of the Assumed Increases in Animal Disease Prevalence during the Study Period}

While it has been noted that the economic progress of Africa is under threat due to continued animal diseases-it has also been positively noted that surveillance can be used for early detection and rapid response against such diseases [29]. However, only appropriate components of such a system should be used to avoid high expenses and cumbersomeness in running it [30]. For this matter, Uganda put in place a national animal health passive surveillance system in 1993 coincidentally at the same time with the civil sector reforms and restructuring. While the submission of the animal health reports per year were stable at an average of $81 \%$ before the reforms; the reform period was characterized by unstable and erratic submissions (Table 1, Figure 1) leading to an average of only $47.06 \%$ in 
16 years and at a very wide standard deviation of $24.41 \%$ from the mean (Table 2 ). The trend of animal health report submissions was on average in the negative or tended to reduce with time at correlation of minus (-) $27.3 \%$ albeit at $p$-value $>0.05$ in 16 years (Table 3 and Figure 2).

From the above results; it was seen that the first casualty of the veterinary reforms was the national animal health surveillance system itself which was affected negatively by erratic and on average reducing submissions of reports with time. By policy and in reference to standing regulations; animal health passive report submissions are expected regularly and in Uganda at least once a month from each DVO to enable appropriate disease threat actions locally while also informing the African Union - Interafrican Bureau for Animal Resources and the OIE authorities. Emergency reports can be submitted immediately for example those due to disease outbreaks and sudden and or high vector prevalence. While the study in general on average showed that national animal health report submissions were declining-but there were also periods when they all of a sudden spiked up. Spiking up was especially during times when projects like the: Livestock Services Project, Germany Technical Cooperation (up to 1996), Pan-African Rinderpest Campaign \& Pan African Control of Epizootics (from 1999 to 2007) provided funding and technical logistics at the center and in field animal health services albeit not in a sustainable way. The Germany Technical Cooperation initiated the systematic development of an organized epidemio - surveillance system in Uganda originally research based but later handed over to the CVO. This gesture was followed by the Pan-African Rinderpest Campaign, Livestock Services Project and Pan African Control of Epizootics Program. Pan African Control of Epizootics consolidated the epidemio-surveillance systems in Uganda 1999-2007 but made recommendations at termination to strengthen epidemio-surveillance networks as an essential and integral part of any future animal disease control program [57].

After termination of the above programs by 2007 ; the national animal health surveillance system again experienced acute inadequate funding for logistics and technical work in animal disease control. This resulted in very low performance with year 2010 recording an average of $12.72 \%$ animal health report submissions-the lowest ever since inception of the system (Table 1 \& Figure 1). Thereafter; submissions started to struggle upwards in unsure jerks under the Livestock Disease Control. The Livestock Disease Control Project replaced the expired projects such as the Pan African Control of Epizootics to cater for national animal disease control. Livestock Disease Control Project funding was inadequate but also lacked direction or management to enable strategic use. So the reforms affected sources of funding for epidemio-surveillance and disease control. In addition; they affected the source or origin of the animal health reports-the local governments which had been decentralized and technical staff were made to report to local councils not the CVO. This phenomenon broke down the central chain of veterinary command. Such a chain is required for 
mandatory reporting and actions on disease threats.

The study further showed that contagious and major animal disease cases increased by $46.1 \%$ (Table 4 ) despite animal health report submissions decreasing to only $46.07 \%$ in 16 years. Increase in cases was therefore related to an increase in disease and or disease outbreaks since fewer measures were being put in place due to negative effects of the reforms on animal disease control under a decentralized and lowly funded system. Increased animal disease presence means a malfunctioning delivery of veterinary regulatory services' system attributed primarily to effects of the reforms and decentralization-which was a deviation away from the central chain of veterinary command. Related to animal and public health disease upsurge during the reform and thus study period-the economically crippling FMD showed a very high association between the cattle corridor areas and the non-cattle corridor areas by a very high positive $83.3 \%$ at $p$-value $<0.05$ level (Table 5). Meanwhile, regression of this relationship showed that with other factors held constant and on average: a high $69.5 \%$ of all FMD outbreaks which occurred in the non-cattle corridor area in Uganda came from the seasonally semi-arid cattle corridor area (Table 6(a) \& Table 6(b)). Controlling FMD in the cattle corridor would rid $69.5 \%$ of this disease in the non-cattle corridor area too. It means that the remaining $30.5 \%$ of this disease in the non-cattle corridor area comes from within or other areas of Uganda and beyond.

Equally-the study showed that there was a high positive association between the numbers of suspected rabid animal bites in man and deaths in man to rabies with a correlation of positive $65.3 \%$ (Table 7). Further regression of this relationship showed that with other conditions held constant; on average $42.7 \%$ of all observed human deaths from rabies disease we attributed to the number of bites by suspected rabid animals (Table 8 (a) \& Table 8 (b)). In summary-the more the suspected rabid animal bites in were reported in man, the more deaths due to rabies were also reported in man. Internationally; the canidae that includes dogs are responsible for $99 \%$ of all rabies cases in man due to their infected bites and scratches [58]. The low national $47.063 \%$ report returns in 16 years seem to have among others acted as a factor in the regression results of $42.7 \%$ deaths in man attributed to bites by suspected rabid animals. It would require higher percentages of report submissions backed-up by active surveillance to get the actual suspected rabid animal bite and deaths in man due to rabies diseases [28]. However, being a public health concern, the passive animal health surveillance system was still sensitive enough to warrant actions to control and prevent rabies disease in pets and man. On the other hand-only bites from suspected rabid animals were used in the study leaving the majority albeit infected bites not reported and or not used in the study and infected scratches. Furthermore to improve passive surveillance reporting on rabies, the report forms used by the DVOs require reform to capture all modes of transmission of rabies from animals to man among others. 
Related; in the same 16 years of the study period; roundworm infestation increased in pigs by a high $69.4 \%$ at $p$-value $<0.05$ (Table 9) with time and a fair regression of an average of $48.2 \%$ (Table 10(a) \& Table 10(b)) with time being the predictor or constant factor. During the same time-vaccine issuance or availability for use in the field to control animal diseases by DVOs declined by negative or (-) $64.3 \%$ with a regression of an average of $41.3 \%$ with time/years being the independent factor (Table 11, Table 12(a) \& Table 12(b)). The staffing of veterinary personnel during this period also saw sharp declines by $92 \%$ between 1997 and 1998 immediately on enacting of the local government law that decentralized the delivery of veterinary extension services during the reform period thus affecting the mandatory veterinary service delivery at grass root level (Figure 3). One of the few positive effects of the reforms is that the private veterinary services function and activities improved and continue to do so but require further institutional development support.

\subsection{The Primary Cause for Increases in Animal Disease Prevalence during the Study Period}

The study confirmed that: animal health reporting declined; the contagious and major animal diseases increased while vaccine availability and or use decreased during the study/reform period. There was also an increase in infestations of diseases such the roundworms in pigs and a major reduction in local government veterinary personnel who are responsible for grass-root/household delivery of the public/regulatory veterinary extension services. Such a negative phenomenon precipitated after the reforms as the study findings confirmed led to a scientifically backed conclusion that the veterinary institutional reform policies were the primary cause for animal disease prevalence increases. Increased animal diseases also meant that there were inadequate or inefficient mechanisms for the delivery of mandatory veterinary regulatory services in the country precipitated by the reforms. This was also an indicator of a breakdown of the internal institutional quality management system for the delivery of veterinary services in the whole country.

\subsection{Factors Associated with Animal Disease Increment during the Study Period}

There were two sets of factors. The first set was the internal veterinary institution factors which can be within reach of control or can be managed or mitigated by the institution. This set included: policy reforms; how effective the national animal health passive surveillance system was implemented; the varied livestock production systems especially the vulnerable pastoralist and communal grazing systems; governance and quality management practices of the veterinary institution. The second set was the external or shock veterinary institution factors. These external factors are largely out of reach of the veterinary institution and cannot not easily be controlled or managed by the veterinary institution 
alone requiring partnerships and collaboration at national and international level. The external/shock factors were: insecurity and the globalized: economics; adverse climatic changes and epidemics.

\subsection{Impact of Internal and External Veterinary Institution Factors on Veterinary Regulatory Services in Animal Health}

Veterinary regulatory services are of public good and to be offered to the public in a mandatory or obligatory way as required by specific regulations. The imperfect reform policy impacted and drastically reduced the delivery of veterinary regulatory services as related to: animal disease control; veterinary public health; animal welfare; food safety; level playing field for trade in livestock products; law and order in the sector and the regulation of the veterinary profession. This in totality culminated in increased animal diseases in the country as an indicator. By extrapolation - the increased contagious, major animal diseases and public health related diseases due to policy reforms contributes to the declines in livestock productivity through: morbidity and mortality resulting in losses of: meat; milk; hides and skins; eggs; wool; manure and animal traction [59]. Related in Uganda; it had been observed that an estimated annual loss of 86.3 million US\$ was being incurred per year in the livestock sector attributed to diseases [12]. It had been further noted that such diseases cause direct visible production losses of: illnesses-stunting and deaths; direct invisible losses of fertility and indirect losses of: mitigation to disease and control costs; human health impact and foregone revenues [60]. FMD as an example of a contagious and major disease in Uganda has: direct impacts leading to reductions in animal production and indirect impacts leading to extra disease control costs; loss of revenue and loss of market access [61]. Some animal diseases also cause natural disease in man (zoonoses) such as rabies.

\subsection{Quality Management Approaches to Improve Performance in the Delivery of the Veterinary Regulatory Services in the Country}

The centralized chain of veterinary command system was in use from year 1908 until 1993 when the most radical civil sector reform initiatives were made [62] up to 1997 when the decentralization law related to extension services was enacted. The reform period 1993 to 1997 was basically the time when the associated animal health quality management system also started to break down. This culminated in the increase of cases of contagious and major animal diseases. Further reforms in policy are required as part of a national animal health quality management system. Such a quality management system should have the following components: a quality policy; quality assurance; quality control and continuous quality improvements in animal health. These processes should be made aware to and fully participatory by all animal industry value chain stakeholders. The processes should also be: management - staff - customer or client focused. Such an objective would be best delivered by a recentralized veterinary 
chain of command with specifically delegated decongestion points at local governments through the mandatory veterinary regulatory services system.

\section{Conclusion}

The study met its objectives since it established that: Animal disease prevalence increased during the policy reform period under study by $46.1 \%$ and that the primary cause was attributed to the reform policies and restructuring that negatively affected the effectiveness and efficiency of the central chain of veterinary command system. However, for any system and organization-there were confounding or other inherent internal (manageable) and external or shock (not easily manageable) factors of the veterinary institution. Further, the impact of increased disease was enumerated and quality management approaches to improve veterinary regulatory service delivery identified. In conclusion: It was recommended that further fully participatory stakeholder policy reforms to practically recentralize the chain of veterinary command and objectively review the national passive animal health surveillance system be undertaken. Further, a quality management system which is staff - management - client focused should be put in place to administer these changes and enable efficient delivery of mandatory veterinary regulatory services in the country.

\section{Acknowledgements}

My family of the "Wanderemas" who offered untiring love and comfort that enable me to undertake research on the subject matter: Bi-Bunaisanga Asiimiwe Umugasha Weere Baaba Wimungagi.

The Director of Animal Resources; the Department of Animal Health; the Division of Veterinary Inspection and Regulations and the Epidemiology Unit in the Ministry of Agriculture Animal Industry and Fisheries-Entebbe, Uganda for their technical assistance in this study and dedication to service delivery in animal health.

All the: District Veterinary Officers; the public and private sector: Veterinary Surgeons/Veterinary Doctors; the Para-Veterinarians and Support Staff who did and continue to work with the national animal health surveillance system.

\section{Conflicts of Interest}

The authors declare no conflicts of interest regarding the publication of this paper.

\section{References}

[1] Animal Diseases Act Chapter 38 (2000). https://ulii.org/node/23789

[2] Animals (Prevention of Cruelty) Chapter 39 (1957). https://ulii.org/search/ulii/Animals\%20\%28Prevention\%20of\%20Cruelty\%29\%20Ac $\underline{\mathrm{t} \% 20}$

[3] Animals (Straying) Act Chapter 40 (1922). 
https://ulii.org/search/ulii/Animals\%20\%28Straying\%29\%20Act

[4] Cattle Grazing Act Chapter 42 (1945).

https://ulii.org/search/ulii/Cattle\%20Grazing\%20Act

[5] Cattle Traders Act Chapter 43 (2000). https://ulii.org/ug/legislation/consolidated-act/43

[6] Rabies Act Chapter 44 (1935). https://ulii.org/search/ulii/Rabies\%20Act

[7] Hide and Skin Trade Act Chapter 89 (1951). https://ulii.org/ug/legislation/consolidated-act/89

[8] Veterinary Surgeons Act Chapter 277 (1958). https://ulii.org/search/ulii/Veterinary\%20Surgeons\%20Act

[9] National Drug Policy and Authority Act Chapter 206 (1993). https://ulii.org/search/ulii/National\%20Drug\%20Policy\%20and\%20Authority\%20A ct

[10] Dairy Industry Act Chapter 85 (2000). https://ulii.org/search/ulii/Dairy\%20Industry\%20Act

[11] (1935) Public Health Act Chapter 281. https://ulii.org/search/ulii/Public\%20Health\%20Act

[12] Ministry of Agriculture, Animal Industry and Fisheries (2010) Agriculture for Food and Income Security. Agricultural Sector Development Strategy and Investment Plan 2010/11-2014/15. 25-65.

https://nutrition.opm.go.ug/wp-content/uploads/2017/05/Agricultural-Sector-Devel opment-Strategy-Investment-Plan.pdf

[13] FAO (1999) Effects of Structural Adjustment Programmes on the Delivery of Veterinary Services in Africa. FAO, Rome, 1-7. http://www.fao.org/3/a-ah933e.pdf

[14] FAO (2002) Improved Animal Health for Poverty Reduction and Sustainable Livelihoods. Animal Production and Health Paper 153, Animal Production and Health Division FAO Agriculture Department, 15-18.

http://www.fao.org/3/a-y3542e.pdf

[15] FAO (2001) Reform of Veterinary Services: A Policy Framework. Animal Production and Health Division FAO, Rome, 1-14.

http://www.fao.org/3/a-ah931e.pdf

[16] Cheneau, Y., El Idrissi, A.H. and Ward, D. (2004) An Assessment of the Strengths and Weaknesses of Current Veterinary Systems in the Developing World. Revue Scientifique et Technique, 23, 351-359. http://www.hubrural.org/IMG/pdf/cheneau.pdf

[17] FAO (2005) Livestock Sector Brief, Uganda. Livestock Information-Sector Analysis and Policy Branch, FAO, Rome, 1-3.

http://www.fao.org/ag/againfo/resources/en/publications/sector_briefs/lsb_UGA.pd $\underline{f}$

[18] Bashaasha, B., Mangheni, M.N. and Nkona, E. (2011) Decentralization of Rural Service Delivery in Uganda. IFPRI, 1-3.

http://citeseerx.ist.psu.edu/viewdoc/download?doi=10.1.1.226.2742\&rep=rep1\&type $=\mathrm{pdf}$

[19] FAO (2009) Poultry Policies, Legislation and Strategies in Uganda. Rome. http://www.fao.org/docrep/013/al691e/al691e00.pdf

[20] Ssewanyana, S., Matovu, J.M. and Twimukye, E. Building on Growth in Uganda. 51. http://siteresources.worldbank.org/AFRICAEXT/Resources/258643-1271798012256 /Uganda-growth.pdf 
[21] Joughin, J. and Kjaer, A.M. (2010) The Politics of Agricultural Policy Reform: The Case of Uganda. Forum for Development Studies. 1-20.

https://www.researchgate.net/publication/237218155_The_Politics_of_Agricultural _Policy_Reform_The_Case_of_Uganda https://doi.org/10.1080/08039410903558277

[22] Rwamigisa, P.B., Birner, R., Mangheni, M.N. and Semana, A. (2013) How to Promote Institutional Reforms in the Agricultural Sector? A Case Study of Uganda's National Agricultural Advisory Services (NAADS). International Conference on the "Political Economy of Agricultural Policy in Africa", Pretoria, 18-20 March 2013, $1-25$.

http://www.bing.com/search?q=Rwamigisa $\% 2 \mathrm{C}+\mathrm{P} .+\mathrm{B} . \% 2 \mathrm{C}+$ Birner $\% 2 \mathrm{C}+\mathrm{R} . \% 2 \mathrm{C}+\mathrm{M}$ anghe-

ni\%2C+M.+N.\%2C+\%26+Semana $\% 2 \mathrm{C}+\mathrm{A} . \% 2 \mathrm{C}+2013 \& \mathrm{src}=\mathrm{IE}-\mathrm{SearchBox} \& \mathrm{FORM}=$ IE8SRC

[23] Andersson, K.P., Fleischman, F., Jagger, P., Luckert, M., Meinzen-Dick, R., Mwangi, E., et al. Unpacking Decentralization: A Case Study of Uganda's Forestry Department. 1-28.

https://www.colorado.edu/ibs/cgnr/andersson/papers/SANREM\%20Decentralizatio n\%20submission\%20to\%20CAPRi\%20WP.pdf

[24] OIE (2011) Terrestrial Animal Health Code Twentieth Edition. 14-24. https://www.oie.int/doc/ged/D10905.pdf

[25] Trish, S. and Dr Kasirye, F. (2002) Veterinary Services in the Horn of Africa, Where Are We Now? A Review of Animal Health Policies and Institutions Focusing in Pastoral Areas. Community-Based Animal Health and Participatory Epidemiology Unit Pan African Programme for the Control of Epizootics African Union's Interafrican Bureau for Animal Resources. 16-21.

https://www.google.com/search?q=COMMUNITY+ANIMAL+HEALTH+SERVIC $\mathrm{ES}+\mathrm{IN}+\mathrm{HORN}+\mathrm{OF}+\mathrm{AFRICA}+-+\mathrm{KASIRYE}$

[26] Cheneau, Y. (1985) Prevalence of Rinderpest Strategy of Pan African Campaign. Revue Scientifique et Technique, 4, 415. http://www.oie.int/doc/ged/D8832.pdf

[27] Ayebazibwe, C., Tjørnehøj Kirsten, K., Mwiine, F.N., Muwanika, V.B., Ademun Okurut, A.N., Siegismund Hans, R., et al. (2010) Patterns, Risk Factors and Characteristics of Reported and Perceived Foot-and-Mouth Disease (FMD) in Uganda. Tropical Animal Health and Production, 42, 1547-1559.

http://www.researchgate.net/profile/Anna_Rose_Ademun_Okurut/publications/?pu bType $=$ article

[28] Fèvre, E.M., Kaboyo, R.W., Persson, V., Edelsten, M., Coleman, P.G. and Cleaveland, S. (2005) The Epidemiology of Animal Bite Injuries in Uganda and Projections of the Burden of Rabies. Tropical Medicine \& International Health, 10, 790-798. https://onlinelibrary.wiley.com/doi/pdf/10.1111/j.1365-3156.2005.01447.x https://doi.org/10.1111/j.1365-3156.2005.01447.x

[29] Hassan, A.M. (2007) A Strategy for Strengthening the National Epidemiological Surveillance Systems in Africa. 125-127. http://www.oie.int/doc/ged/D4540.PDF

[30] Frerichs, R. (1991) Epidemiological Surveillance in Developing Countries. Annual Review of Public Health, 12, 257-280.

https://doi.org/10.1146/annurev.pu.12.050191.001353 http://www.annualreviews.org/doi/abs/10.1146/annurev.pu.12.050191.001353

[31] Putt, S.N.H., Shaw, A.P.M., Woods, A.J., Tayler, L. and James, A.D. (1988) Veterinary Epidemiology and Economics in Africa-A Manual for Use in the Designing 
and Appraisal of Livestock Health Policy. 1-48. http://pdf.usaid.gov/pdf_docs/PNAAW757.pdf

[32] MAAIF (2001) National Policy for the Delivery of Veterinary Services. 1-45.

[33] OIE (2014) Terrestrial Animal Health Code. 23rd Edition, 79-108. https://www.oie.int/doc/ged/D13850.pdf

[34] Msellati, L., Commault, J. and Dehove, A. (2012) Good Veterinary Governance: Definition, Measurement and Challenges. Revue Scientifique et Technique, 31, 413-430. http://www.ncbi.nlm.nih.gov/pubmed/23413724 https://doi.org/10.20506/rst.31.2.2130

[35] Mark, W., Rosegrant, S.A., Cline, W.L., Timothy, B., Sulser, R. and Valmonte-Santos, A. (2005) Looking Ahead: Long-Term Prospects for Africa's Agricultural Development and Food Security. 2020 Discussion Paper No. 41, International Food Policy Research Institute, Washington DC, 1-3.

https://ageconsearch.umn.edu/record/42255/files/vp41.pdf

[36] Kirsten, G., Daniel, M. and Dyna, M. (2012) Researching Livelihoods and Services Affected by Conflict-Livelihoods, Basic Services and Social Protection in Northern Uganda and Karamoja. Working Paper 4, 1-7.

https://www.odi.org/sites/odi.org.uk/files/odi-assets/publications-opinion-files/778 1.pdf

[37] James Illango (1992) Rabies in Uganda. Proceedings of the International Conference on Epidemiology Control and Prevention of Rabies in Eastern and Southern Africa, Lusaka, 2-5 June 1992, 9-13.

http://citeseerx.ist.psu.edu/viewdoc/download?doi=10.1.1.462.5772\&rep=rep1\&type $=\mathrm{pdf}$

[38] Rutebarika, C.S. (1999) Rabies in Uganda - Proceedings of the Southern and Eastern Africa Rabies Group/World Health Organization Meeting, Entebbe, Uganda. 51-54. http://erepository.uonbi.ac.ke/bitstream/handle/11295/31986/Proceedings\%20of\%2 0the\%20Southern\%20and\%20Eastern.PDF? sequence $=1$ \&isAllowed $=\mathrm{y}$

[39] Hatch, C., Snedoon, J. and Jalloh, G. (2004) A Descriptive Study of Urban Rabies during the Civil War in Sierra Leone: 1995-2001. Tropical Animal Health and Production, 36, 321-334.

https://link.springer.com/article/10.1023/B\%3ATROP.0000026668.54427.e9

[40] OIE (2011) Terrestrial Animal Health Code. 20th Edition, 73-76. https://www.oie.int/doc/ged/D10905.pdf

[41] Kung Leong, T., Zakuan, N. and Saman, M. (2014) Review of Quality Management System Research in Construction Industry. International Journal of Productivity and Quality Management, 13, 113-117.

https://www.researchgate.net/publication/264821575_Review_of_quality_managem ent_system_research_in_construction_industry

[42] Silva, A. (2005) The Ten Commandments of Quality Management. 1-17. https://books.google.co.ug/books?id=Ffht9Xz1PT4C\&printsec=frontcover\&dq=Qu ali-

ty+Management+Research\&hl=en\&sa=X\&ved=0ahUKEwjziqfRx7PWAhXEBcAK HWSQAfQQ6AEIRTAG\#v=onepage\&q=Quality\%20Management\%20Research\&f= false

[43] Jaafreh, A.B. and Al-albedallat, A.Z. (2012) The Effect of Quality Management Practices on Organizational Performance in Jordan: An Empirical Study. International Journal of Financial Research, 4, 93-109.

[44] Elshaer, I.A. and Augustyn, M.M. (2016) Direct Effects of Quality Management on 
Competitive Advantage. International Journal of Quality \& Reliability Management, 33, 1286-1310. https://doi.org/10.1108/IJQRM-07-2014-0086

[45] Perry Brian, D., Delia, G. and Keith, S. (2013) Current Drivers and Future Directions of Global Livestock Disease Dynamics. PNAS, 110, 20871-20877.

http://www.pnas.org/content/early/2011/05/10/1012953108.full.pdf+html https://doi.org/10.1073/pnas.1012953108

[46] Ocaido, M., Otim, C.P. and Kakaire, D. (2009) Impact of Major Diseases and Vectors in Smallholder Cattle Production Systems in Different Agro-Ecological Zones and Farming Systems in Uganda. Livestock Research for Rural Development, 21. http://www.lrrd.org/lrrd21/9/ocai21155.htm

[47] Ocaido, M., Kristina, R. and Grace, D. (2013) Food Safety \& Zoonotic Hazards in Pig Value Chains in East Africa. 1-15.

https://www.slideshare.net/ILRI/food-safety-and-zoonotic-hazards-in-pig-value-ch ains-in-east-africa

[48] Perry, B.D., Randolph, T.F., McDermott, J.J., Sones, K.R. and Thornton, P.K. (2002) Investing in Animal Health Research to Alleviate Poverty. 2-77.

https://core.ac.uk/download/pdf/41703290.pdf

[49] Perry, B. and Grace, D. (2009) The Impacts of Livestock Diseases and Their Control on Growth and Development Processes That Are Pro-Poor. Philosophical Transactions of the Royal Society B: Biological Sciences, 364, 2643-2655.

http://www.ncbi.nlm.nih.gov/pmc/articles/PMC2865091/ https://doi.org/10.1098/rstb.2009.0097

[50] Intriligator, M.D. (2003) Globalization of the World Economy: Potential Benefits \& Costs and a Net Assessment. No. 33, 1-11. http://www.milkeninstitute.org/publications/view/188

[51] USAID (2013) Uganda Climate Change Vulnerability Assessment Report. 1-9. http://community.eldis.org/.5b9bfce3/ARCC-Uganda\%20VA-Report.pdf

[52] CIGI (2009) African's Climate Change Reality: The African Initiative Congress on Climate Change. 1-5. https://www.files.ethz.ch/isn/116191/AI\%20Conference\%20Report_0.pdf

[53] Taylor, L.H., Mlatham, S. and Woolhouse, M.E.J. (2001) Risk Factors for Human Disease Emergence. Philosophical Transactions of the Royal Society B: Biological Sciences, 356, 983-987. http://rstb.royalsocietypublishing.org/content/356/1411/983

[54] Joyce Catherine, M., Stefanie, S., Anthony, S., Humphreys, J. and Kalb, G. (2011) Australian Doctors' Satisfaction with Their Work: Results from the Mabel Longitudinal Survey of Doctors. The Medical Journal of Australia, 194, 31-33.

https://www.mja.com.au/journal/2011/194/1/australian-doctors-satisfaction-their-w ork-results-mabel-longitudinal-survey

[55] Mathers, N., Fox, N. and Hunn, A. (2009) Surveys and Questionnaires. 4-39. https://www.rds-yh.nihr.ac.uk/wp-content/uploads/2013/05/12_Surveys_and_Quest ionnaires_Revision_2009.pdf

[56] OIE (2010) Terrestrial Animal Health Code. Twentieth Edition, 22-23. https://www.oie.int/doc/ged/D7597.pdf

[57] Consortium, A. (2006) Final Evaluation of the Pan-African Program for the Control of Epizootics (PACE). Final Report, 1-6.

http://archive.au.int/collect/ibarcoll/import/English/Final\%20Evaluation\%20of\%20t he\%20Pan\%20African\%20Programme\%20for\%20the\%20control\%20of\%20Epizooti cs_E.pdf

[58] World Health Organization (2017). 
http://www.who.int/rabies/epidemiology/Rabiessurveillance.pdf

[59] Tambi, E.N., Main, W., Mukhebi, A.W. and Randolp, T.F. (1999) Economic Impact Assessment of Rinderpest Control in Africa. Revue Scientifique et Technique, 18, 458-477. http://www.oie.int/doc/ged/d9255.pdf

[60] IFAH (2012) The Cost of Animal Diseases. A Report by the International Animal Health Federation, 1-37.

https://www.healthforanimals.org/component/attachments/attachments.html?task= attachment\&id=34

[61] Rushton, J., Knight-Jones, T., Donaldson, A., de Leeuw, P., Ferrari, G. and Domenech, J. The Impact of Foot and Mouth Disease. 1-27.

https://www.oie.int/doc/ged/D11888.pdf

[62] Robinson, M. (2004) Managing Successful Governance Reforms: Lessons of Design and Implementation-The Political Economy of Governance Reforms in Uganda. World Bank, Washington DC, 8-11.

http://www1.worldbank.org/publicsector/PREMWK2005/poleconomy/Uganda.doc 